\title{
Apresentação
}

\section{CMU 30 anos. Histórias e memórias construídas com base em seu acervo}

Este número da Resgate - Revista Interdisciplinar de Cultura celebra os 30 anos do Centro de Memória-Unicamp. Um projeto político que se consolidou ao longo destes anos e hoje conta com um vasto e valioso acervo, distribuído em aproximadamente 150 conjuntos documentais, composto por documentos textuais, fotográficos, cartográficos, sonoros e filmográficos, datados entre o final do século XVIII e início do século XXI. São documentos de interesse histórico, que possibilitam retraçar as transformações ocorridas na região de Campinas desde os ciclos da cana-de-açúcar e do café, até a industrialização, constituindo uma matriz de informações para estudos e pesquisas multidisciplinares relativas à questão da memória e da história.

Celebramos, sobretudo, o valioso e indispensável trabalho cotidiano de funcionários técnicos administrativos, pesquisadores, docentes e estagiários da Unicamp que atuaram e atuam com seus saberes na construção e consolidação do CMU. Por outro lado, o acervo ganha sentido e visibilidade com a atuação de investigadores que enfrentam a árdua e, ao mesmo tempo, prazerosa tarefa de remexer, revirar as longas séries documentais, perguntando, desconfiando das evidências, das provas, à primeira vista consolidadas. Assim, o arquivo deixa de ser um repositório fechado de informações sobre o passado e assinala para um povir prenhe de instigantes histórias que, de acordo com as indagações do pesquisador, podem adquirir significados em escalas distintas.

Desse modo, o presente número da Resgate tem a satisfação de apresentar a seus leitores um conjunto de trabalhos cujos textos têm em comum as fontes documentais do acervo do CMU. O trabalho de autoria de Ricardo Pirola, Desafios e estratégias na construção de biografias de escravos, abre o número com uma instigante história de escravos. Para a escritura do texto, o autor partiu de um plano de insurreição descoberto em Campinas no ano de 1832, e aborda os desafios enfrentados na narrativa de trajetórias de "gente comum", no caso, escravos e forros. Na sequência, Maria Alice Rosa Ribeiro, em seu artigo intitulado Açúcar, café, escravos e dinheiro a prêmio: Campinas, 1817-1861, analisa, por meio do inventário post mortem, a riqueza amealhada pelo cafeicultor Francisco Egydio e evidencia as três dimensões das atividades empreendidas por ele: como grande proprietário de terras com lavouras de cana de açúcar e de café, como senhor de engenho e cafeicultor, como grande proprietário de escravos e, ainda, como um "emprestador de dinheiro a prêmio". O artigo de Juliana Gesuelli Meirelles, Histórias de Campinas no período colonial (1775-1822): historiografia e documentação, expõe as potencialidades do acervo do CMU para as pesquisas relativas ao período colonial da região de Campinas, fontes ainda pouco exploradas pelos pesquisadores. Divórcio e Desquite na Cidade de Campinas (1890-1938), texto de Cristiane Fernandes Lopes Veiga, a partir das ações de divórcio e desquite do fundo do Tribunal de Justiça da Comarca de Campinas, sugere que muitas mulheres não mais estavam apenas preocupadas em cumprir o papel de mãe e esposa e revela os conflitos de um momento importante para a reelaboração das identidades de gênero, no contexto do final do século XIX. O artigo elaborado por João Paulo Berto, intitulado Práticas e Representações Fúnebres: preparações para a morte na Campinas oitocentista, e construído a partir de fontes distintas, como jornais e testamentos, traz à tona os rituais fúnebres situados no século XIX e as maneiras como as liturgias institucionais da Igreja Católica, relativas a estes rituais, foram ressignificadas ao longo do tempo. Eliane Morelli Abrahão, com o texto Morar em Campinas, usos e costumes (1850-1900), analisa os hábitos alimentares, os modos de morar e os protocolos de recepção para jantares e reuniões da elite cafeeira campineira, entre 1850 e 1900. Por fim, o texto Cidade, memória e sensibilidade, de Maria Sílvia Duarte Hadler, nos leva a adentrar na cidade para compreender os processos socioculturais que constituíram uma educação urbana das sensibilidades, localizada nos anos finais de 1950 e de 1960, marcada pelos ritmos acelerados dos automóveis.

Na seção recém-criada Notas de Pesquisa, na qual apresentamos trabalhos em fase inicial de investiga- 
Apresentação

ção, o texto Criminosos, Fugitivos e Litigantes pela Liberdade: os Escravos Traficados para Campinas, 1860-1888, de Letícia Graziela de Freitas Lemes, apresenta alguns dados de transações de compra e venda de escravos e a experiência do tráfico na vida desses cativos, arrolados por meio do cruzamento de processos criminais envolvendo escravos, ações de liberdade e anúncios de fugas no jornal Gaz̧eta de Campinas, cotejadas com os registros do pagamento do imposto da Meia Sisa na Coletoria e Recebedoria de Rendas de Campinas.

Finalmente, três resenhas apresentam obras recém-lançadas. As duas primeiras têm em comum as fontes do acervo do CMU em suas pesquisas e a última reúne uma coletânea de textos apresentados no VII Seminário Nacional do Centro de Memória, realizado em 2012. Adriana Koyama resenha o livro O Almanaque, a locomotiva da cidade moderna: Campinas, décadas de 1870 e 1880, de autoria de Maria Carolina Bovério Galzerani, que será publicado pelo CMU ainda este ano. À Olga von Simson coube resenhar as obras de Jorge Alves de Lima, O Ovo da serpente - Campinas 1889 e O Retorno da Serpente - Campinas 1890; e Claudia Fortuna resenha Memória, Cidade e educação das Sensibilidades, organizada por Maria Elena Bernardes e Maria Carolina Bovério Galzerani.

Boa leitura e fica o convite ao leitor/pesquisador para explorar o potencial de pesquisa dos 150 conjuntos documentais do acervo sob a guarda do $\mathrm{CMU}$, dos quais outras instigantes histórias podem emergir. 